\title{
Title: Do All CSR News Affect Market Value Equally?
}

Running head: $\underline{\text { CSR News and Market Value }}$

\begin{abstract}
Purpose - This research explores the effects that media coverage of Corporate Social Responsibility (CSR) news related to primary stakeholders (e.g., customers, employees and investors) and secondary stakeholders (e.g., community) have on the market value of companies, measured as the impact generated in the positive and negative abnormal returns for those companies.
\end{abstract}

Design/methodology/approach - Using a sample of 195 online articles published in the most important Spanish business newspaper during 2015, we implement an event study and a regression analysis that confirm the importance of CSR news for corporate financial goals.

Findings - The findings show that negative CSR news related to primary stakeholders such as investors and customers generate significant abnormal returns for companies that are notably larger than the abnormal returns generated by secondary stakeholders (e.g., community). Similarly, positive news related to primary stakeholders such as employees are the only positive news that affect market reactions significantly.

Originality/value - The study provides an empirical analysis that clarifies how media coverage of different types of CSR news affect the market value of companies. In doing so, the paper contributes to previous literature significantly, because scant research exists that has compared the differential effects of CSR news focused on primary and secondary stakeholders. The findings are discussed under the premises of the managerial perspective of stakeholder theory.

KEYWORDS - Corporate social responsibility, financial performance, market value, media, stakeholders 


\section{INTRODUCTION}

Media have significant influence on public opinion in the context of Corporate Social Responsibility (CSR) (McCombs and Reynolds, 2002). For example, media affect the stock market by disseminating information, which influences the public agenda and help materialize the goals of companies through shaping their corporate reputations (Tang, 2012; Zhang \& Swanson, 2006). Thus, media play an indispensable role in the dialogues around CSR because it is a channel through which companies communicate their commitment to CSR to the public while it also functions as an independent monitor of companies' practices that safeguards the interests of their stakeholders (Tang, 2012).

For these reasons, researchers have been looking at the link between media coverage of CSR news and market-based measures of corporate financial performance (CFP) for quite some time (Flammer, 2013; Frooman, 1997; Klassen and McLaughlin, 1996; Patten, 2008; Shane and Spicer, 1983; Shiu and Yang, 2017; Wright et al., 1995; Xu et al., 2012). "Indeed, as far back as the early 1970s, Milton Moskowitz (1972) called for empirical proof to verify the commonly held belief that economic incentives could be used to motivate companies to be socially responsible" (Frooman, 1997: 224). However, for the purpose of this research we have observed that these studies provide only limited support for the proposition that shareholders find media coverage of CSR news useful for investment decision making.

In this regard, although most of this literature points toward a positive relationship between CSR news and stock prices (Flammer, 2013; Klassen and McLaughlin, 1996; Shane and Spicer, 1983), it is also observed that previous studies have focused on exploring only very specific types of CSR news. They have mostly explored environmental CSR (Aaron et al., 2012; Flammer, 2013; Klassen and McLaughlin, 1996; Shane and Spicer, 1983; Xu et al., 2012), labor issues (Wright et al., 1995) and philanthropy news (Patten, 2008). However, they have not compared market reactions across these different types of CSR news. In the end, the 
lack of comparison of the impact of media coverage of different CSR news on financial performance highlights that little is still known about whether and how the relationship between CSR news and market value really is articulated (Halme and Laurila, 2009). Thus, a deeper analysis is needed to take into account all the complexity of the CSR concept and see whether all CSR news affect market value equally or not.

Based on this idea, the contribution of our paper is focused on providing an empirical analysis that clarifies how media coverage of CSR news impact on the market value of companies, which will allow us to identify the salience of various types of CSR news and provide useful guidance for companies to articulate their CSR and communication strategies. In doing so, we propose that the managerial perspective of stakeholder theory (Freeman, 1984) provides us with a useful theoretical framework to examine and understand the relationship between CSR news and the abnormal returns for companies in the stock market.

The remainder of the paper is structured as follows. First, we review the existing literature on the media coverage of CSR news and its impact on the abnormal returns for companies in the stock market. This literature review leads to the proposal of several research hypotheses that are explored in the paper. Second, the method is described by paying especial attention to the research design, the content analysis procedure and the sample of news used in the study. Third, the research findings are presented and discussed. Finally, we summarize the most relevant conclusions, managerial implications, limitations and future lines of research derived from the study.

\section{LITERATURE REVIEW}

\section{CSR News and CFP}

Most scholars in the CSR literature have directed special attention to examining the impact of CSR on accounting-based measures of CFP (e.g., ROA, ROE, EPS). However, the 
findings of these papers frequently report inconsistent results on the relationship between CSR and a company's CFP (Hendarto and Purwanto, 2012). More precisely, scholars along this line of research argue that CSR frequently detracts from CFP because any discretionary expenditures on social betterment unnecessarily raise a company's costs, thereby putting it at an economic disadvantage in a competitive market (Jensen, 2002; McWilliams and Siegel, 1997).

In contrast, when exploring the effects of CSR on market-based measures of CFP (i.e., abnormal returns for companies in stock markets), another group of scholars argue that the better a company's CSR performance, the better it can attract resources (Aaron et al., 2012; Flammer, 2013; Hendarto and Purwanto, 2012; Klassen and McLaughlin, 1996; Patten, 2008; Wright et al., 1995) because shareholders appreciate the opportunities that a good CSR reputation bring in terms of obtaining quality employees or market products and services to consumers (Fombrun et al., 2000). From this perspective, CSR is a source of competitive advantage.

In the context of this stream of research, scholars have also highlighted the special role that the media play in market-based returns for companies that invest in CSR (Patten, 2008; Zhang, Wang, \& Fung, 2014). Media affects the stock market by disseminating information to a broad audience, especially to individual shareholders, and broadening public recognition of corporate news. News media also help materialize the goal of CSR, which is to influence the reputation of companies significantly and positively (Zhang and Swanson, 2006). For example, by not covering negative corporate news or describing such events in a more positive light, editors and journalists can limit the damage caused by corporate scandals. At the same time, if editors are more likely to report on negative events occurring at companies, managers face an interesting challenge because these news can cause a strong damage to the companies' record of CSR performance (Luo et al., 2012). Thus, media's coverage of CSR sets the agendas for 
the public and, to some extent, for companies, by raising awareness about CSR news and selectively emphasizing certain aspects of CSR (Tang, 2012).

Along this line, some studies have investigated the market reactions to broad-based CSR media news (Zhang et al., 2014) or announcements covering specific types of CSR news, such as environmental news (Aaron et al., 2012; Flammer, 2013; Klassen and McLaughlin, 1996; Shane and Spicer, 1983; Xu et al., 2012), news concerning employees' labour issues (Wright et al., 1995) and corporate charitable giving (i.e., philantrophy news) (Patten, 2008). While the findings generally indicate statistically significant market reactions, all these studies also highlight that the tone of the media coverage plays a key role in determining market reactions to CSR news (Aaron et al., 2012; Curran and Moran, 2007; Flammer, 2013; Shiu and Yang, 2017; Wright et al., 1995).

As presented by Carroll \& McCombs (2003: 41), it is believed that "the more positive that media coverage is for a particular attribute, the more positively will members of the public perceive that attribute. Conversely, the more negative that media coverage is for a particular attribute, the more negatively will members of the public perceive that attribute". For example, Wright et al. (1995) hypothesize and corroborate that announcements of companies receiving awards for high-quality voluntary affirmative CSR action programs are associated with significant and positive stock returns for those companies, while announcements that convey that companies are guilty of discriminatory practices are associated with significant and negative stock returns for those companies. Similarly, Flammer (2013) demonstrate that shareholders react positively to the announcement of eco-friendly corporate actions, while they react negatively to the announcement of eco-harmful corporate events. Finally, the findings of Curran \& Moran's (2007, p. 529) study show that a trend exists "towards positive and negative announcements having the expected effects on daily returns", although these movements do not seem to be significant. Their data suggest that a company's presence on the FTSE4Good 
UK Index brings some positive returns for companies signaling their CSR, but the market reaction is not significant enough to guarantee this effect to every company.

Therefore, and prior to deepen in the main research goal of this paper, which is to test whether significant differences exist in market reactions to different types of CSR news, we have to corroborate that CSR news have significant effects on the market value of companies. For this purpose, and based on the previous ideas discussed in this section, we first propose the following research hypothesis:

H1: CSR media coverage affects the market value of the company. More specifically, H1a: Positive CSR news will be associated with significant (abnormal) and positive returns for the company.

H1b: Negative CSR news will be associated with significant (abnormal) and negative returns for the company.

We also hypothesize that the intensity of the effect of media coverage of positive CSR news on the market value of a company differs from the intensity of the effect of media coverage of negative CSR news. This is so because negative information is expected to have a larger and longer impact on shareholders' minds than positive information (Curran and Moran, 2007). For example, in his meta-analysis of 27 event studies that have measured the stock market reactions to incidences of socially irresponsible and illicit behavior, Frooman (1997) provides empirical results indicating that acting in a socially responsible and lawful manner is a necessary, though not sufficient, condition for increasing shareholders' wealth. Actually, their findings show that, for companies engaging in socially irresponsible and illicit behavior, the effect on shareholders' wealth is negative (wealth decreases), statistically significant and so substantial in size that the distribution of abnormal returns is shifted nearly a full standard deviation to the left (i.e., negatively) from their expected standard normal distribution. This finding yields the conclusion that socially irresponsible and illegal corporate actions result in 
substantial unrecovered decreases in shareholders' wealth, while positive actions increase wealth but not so intensely. Based on these arguments, we propose the following hypothesis:

H2: There is asymmetry between the effects of positive and negative CSR media coverage on the market value of the company. More specifically, media coverage of a company's negative CSR news will have larger effects on the significant (abnormal) returns for the company than media coverage of a company's positive CSR news.

Types of CSR News and their Impact on Market Value: Primary vs. Secondary Stakeholders

Under the light of the managerial perspective of stakeholder theory (Freeman, 1984), numerous scholars highlight that not all stakeholders are equally powerful to influence companies' CSR performance. In this paper, we base on this idea to argue that CSR news related to those specifically powerful stakeholders will have a larger impact on the market value of companies than other types of CSR news focused on stakeholders who are less salient for companies and their shareholders.

For instance, Clarkson (1995) differentiates between primary and secondary stakeholders, considering the frequency and the direct/indirect character of their exchanges with the company. Specifically, primary stakeholders include those "without whose continuing participation the company cannot survive as a going concern" (Clarkson, 1995: 106). The support of these groups is necessary for the company to exist, and it may have special duties towards them (Gibson, 2000). Secondary stakeholders are not essential for a company's survival and, therefore, they are less powerful (van der Laan et al., 2008). Nevertheless, they still have some influence over CSR performance due to their capacity to mobilize public opinion in favor of (or in opposition to) a company's actions. Along this line, Mitchell et al. (1997) classify stakeholders according to their salience, which is a combination of: a) their power to influence the company, b) the legitimacy of their claims, and c) the urgency of their demands. Primary stakeholders possess the three attributes. Thus, from a company's 
perspective, effectively dealing with primary stakeholders is the key to success (Elijido-Ten et al., 2010). In contrast, secondary stakeholders have legitimate claims on the company, but their demands lack urgency and they do not have enough power to enforce those claims (Godfrey et al., 2009; Mitchell et al., 1997).

On the one hand, investors, employees and customers are primary stakeholders for companies, especially powerful in claiming their rights and determining corporate CSR performance. Primary stakeholders are involved in explicit contracts and direct exchanges with companies. There is reciprocal relationship and mutual dependence (Casciaro and Piskorski, 2005) and their support is necessary for the continuing profitability of the company (Clarkson, 1995). In fact, CSR actions targeting primary stakeholders are highly likely to induce them to engage in increased exchanges with the company, so they may be seen as wholly consistent with the company's profit-making orientation (Godfrey et al., 2009). Thus, the effect of CSR news that impact primary stakeholders on share price changes is expected to be significant and strong, because these pieces of news have a direct effect on the growth and profitability of companies (Halme and Laurila, 2009).

On the other hand, secondary stakeholders are comprised of special interest groups, such as the community and the environment, that are expected to have a lower effect on share price changes (van der Laan et al., 2008). As we have commented previously, secondary stakeholders do not have frequent nor direct exchanges with companies. On the contrary, they hold implicit relationships and the company's dependence on them is weak (van der Laan et al., 2008). A company's relationship with secondary stakeholders is more likely to produce moral capital (versus the exchange capital of primary stakeholders) and to be viewed as voluntary, related in some occasions to social beneficence based on normative or pragmatic appeals (Godfrey et al., 2009). Furthermore, CSR actions focused on secondary stakeholders 
do not always have an effect on profit in the short term, which is a key concern for shareholders investing in the stock market.

Based on these ideas, we propose the third research hypothesis of the paper:

H3: The importance that shareholders give to CSR media coverage varies across different types of CSR news. More specifically, CSR news focused on primary stakeholders have a stronger impact on a company's significant (abnormal) returns than CSR news focused on secondary stakeholders.

\section{SAMPLE DATA}

\section{Data Collection}

To identify CSR news we examined the content of "Expansión", the leading business newspaper in Spain based on their audience and diffusion volumes. Using a list of keywords based on the proposal of Pérez, García de los Salmones, \& López (2015), we identified CSR media coverage by searching the online database of the newspaper. We identified pieces of CSR news related to four key stakeholders (Fombrun et al., 2000): (1) community, (2) customers, (3) employees and (4) investors. We also searched for additional keywords related to the major CSR issues that could be discussed in business news (Pérez et al., 2015). These CSR issues included economic development programs, environmental policy, systems and performance, educational and cultural activities or social and charitable contribution, among others (see Appendix). Some of the CSR news that we found in our research referred to the same CSR story, although at different times. This is so because, as most media, "Expansión" usually continues to publish information about the same event while it is still important for its readers. In these cases, we decided to retain only the first article that referred to each specific CSR story. We also checked that there were not related news about each company during the $[-5 ;+5]$ window around the date that the CSR news was released by the newspaper to avoid bias in the results due to the presence of contaminating events in the same time frame. 
Once these filters were applied, the final sample contained 195 CSR news. For each piece of CSR news that we found, the following items were identified: (1) event date; (2) [$5 ;+5$ ] event window; (3) name of the company, (2) industry, (3) stakeholder group, (5) CSR topic and (4) tone of the discussion. The tone of the discussion was coded into positive or negative. Positive news identified articles reflecting cohesion, co-operation, stability and strength. Negative news reflected conflicts, disorganization, instability and weakness (Zhang \& Swanson, 2006). In the Appendix of this paper, we illustrate an example of the procedure that we followed to code CSR news and create our database.

\section{Characterization of CSR News}

The 195 articles identified for the study related to 37 companies and the 4 stakeholder groups as follows (Table I): community ( $\mathrm{n}=63,32.3 \%, 7$ companies), customers $(\mathrm{n}=58,29.7 \%, 11$ companies), employees ( $\mathrm{n}=28,14.4 \%, 6$ companies) and investors $(\mathrm{n}=46,23.6 \%, 13$ companies). Along this line, we also found some companies that attracted more media attention than others, especially financial companies. For example, 23 articles $(11.8 \%)$ focused on the CSR of Bankia, Santander Bank $(n=19,9.7 \%)$, Caixabank $(n=18,9.2 \%)$ and BBVA $(n=15$, 7.7\%). Nonetheless, this not only happens for financial companies. Two other non-financial companies attracted as much media attention as banks: Iberdrola $(\mathrm{n}=15,7.7 \%)$ and Telefónica $(n=16,8.2 \%)$, from the energy and telecommunications industry respectively. Thus, the findings show that finance was the most visible industry in the Spanish media's coverage of CSR, which is explained by the high-profile of this industry in the country, derived from its high involvement in the latest international recession (Pérez et al., 2015). Other industries, such as energy and basic industries, are also high-profile and have traditionally received great media and public attention. According to this, they were also frequently targeted by the media (Pérez et al., 2015). At the same time, the findings can also be explained by the big size of the 6 companies discussed in these lines. As ranked by the Spanish Stock Market, Santander, 
Telefónica, BBVA, Iberdrola, Caixabank and Bankia are in the Top 20 of the largest companies in the Spanish Stock Market according to their capitalization volume.

\section{EMPIRICAL STUDY}

\section{Study 1 - Event Study}

To analyse the market reaction to CSR news we employed an event study with daily returns (Clacher and Hagendorff, 2012). This methodology analyses stock price changes around the day of the CSR announcement by estimating abnormal returns, defined as the difference between the return actually obtained on a given day and the expected return according to a market model previously defined by the researchers (McWilliams and Siegel, 1997). The estimation period taken to calculate the market model in our paper lasted 250 days, from 270 days to 21 days before the event date (the date of CSR announcement in the newspaper), which was so defined to avoid that the estimation of the model was influenced by the event itself.

Once the market model was estimated, the abnormal returns were calculated in the event window around the event date. Different event windows were chosen to include possible reactions in the share prices before and after the event. Specifically, we selected event windows in two different sections. First, we calculated the abnormal returns in some windows prior to the event date (from one to three days before the event). These windows allowed us to control for possible leaks or rumors that could advance the reaction of the market at the date of the announcement, or the publication on a day when the market was closed (Guo and Mech, 2000; McWilliams and Siegel, 1997). Second, we calculated the abnormal returns between the day before the event and some days after. These windows allowed us to examine the stock market reactions to the CSR news during the first week after publication (Aaron et al., 2012). In addition, by using windows of variable duration we could homogenize the returns of all the 
companies considered for the study and avoid the bias that an inaccurate delimitation of the event window could produce.

To test the null hypothesis that cumulative abnormal returns during the event windows were equal to zero, the statistic based on normalized excess returns was used (Dodd and Warner, 1983). This analysis allowed us to test if the event had a significant impact on the market value of the company. Finally, to test the differences in the abnormal returns we used the Wilcoxon rank-sum test.

\section{Study 1 - Findings}

The results of the event study are presented in Table I, distinguishing between the CSR news that were expected to have a positive and a negative effect on the market value of companies. The table includes, for each event window considered, the average accumulated abnormal return (ACAR) and the test of statistical significance (Dodd and Warner, 1983). In addition to this, to test the differences in the magnitude of the reaction, we present the Wilcoxon rank-sum test. Since we had positive and negative reactions, we applied the test comparing the absolute value of returns.

\section{Insert Table I about here}

The findings indicated the existence of statistically significant abnormal returns in the days around the event date, for both positive and negative CSR news. On the one hand, as previously hypothesized in the paper, media coverage of companies' positive CSR news generated significant and positive abnormal returns for those companies. On the other hand, negative coverage generated significant and negative returns for the companies under scrutiny. Thus, the hypotheses H1a and H1b were confirmed by the findings of our study. In both cases, the largest market reaction $(0.51 \%$ and $-2.75 \%$ for positive and negative CSR news respectively) appeared in the window $[-1 ;+1]$. 
The analysis also showed that significant reactions only occurred within a 3-day window around the event date for positive news, while reactions became non-significant when longer event windows were considered. It is also noticeable that positive news did not provoke anticipated market reactions before their release on the media.

In the case of negative news, a different pattern is observed. On the one hand, market reactions began two days before the event date, which shows an anticipated reaction of shareholders to the publication of negative CSR news. On the other hand, market reactions occurred for as long as four days after the event date. Thus, negative CSR news revealed to the market showed more persistence than positive CSR news.

In summary, the findings of the study confirmed that the stock market reacted very quickly to the release of CSR news. In the case of negative CSR news, a market reaction was observed in the two days prior to the publication of CSR news. Thus, it was confirmed that negative CSR news that were anticipated by the market provoked significant market reactions before the event date. This was not the case when positive CSR news were released. Finally, the findings also showed that, in all the event windows considered for the study, negative reactions were significantly larger than positive reactions. Thus, the hypothesis $\mathrm{H} 2$ was also confirmed in this research.

\section{Study 2 - Regression Analysis}

As a last step in our analyses, we also estimated a linear regression analysis to determine if significant differences existed in the market reaction to different types of CSR news. The analysis was made for the abnormal returns in the window $[-1 ;+1]$. According to the results showed in the Study 1, this window is the most relevant for the purposes of our research since it reflects the immediate effect produced by CSR news and it presents the largest and most significant abnormal returns for both positive and negative CSR news. The estimation was 
made by applying ordinary least squares (OLS), using the White correction to control for the heteroscedasticity that usually appears in these types of cross-section analyses.

The proposed model was:

$$
\begin{array}{r}
C A R=\left(\alpha_{1}+\varphi_{1} S I G\right) \text { COMM }+\left(\alpha_{2}+\varphi_{2} S I G\right) \text { CUST }+\left(\alpha_{3}+\varphi_{3} S I G\right) \text { EMPL }+\left(\alpha_{4}+\right. \\
\left.\varphi_{4} S I G\right) I N V+\left(\alpha_{5}+\varphi_{5} S I G\right) S A L E S+\left(\alpha_{6}+\varphi_{6} S I G\right) R O E+\left(\alpha_{7}+\varphi_{7} S I G\right) P D C T+\varepsilon
\end{array}
$$

The dependent variable (CAR) was the cumulative abnormal return in the window [-1; +1 . We also defined some dummy variables, included as explanatory variables in the model, to study the differences in the market reaction according to each type of CSR news. For each type of news, we defined a variable that took the value one for CSR news related to that specific topic and zero otherwise. The types of CSR news considered for the study were each of the stakeholder groups previously defined in the paper: community (COMM), customers (CUST), employees (EMPL) and investors (INV). As discussed in the literature review section, while customers, employees and investors represent primary stakeholders for companies, the community is classified as a secondary stakeholder.

In addition to these dummy variables, control variables were also included in the analysis to reduce bias in the results. Specifically, we introduced (1) corporate size (SALES), measured as the log of the sales of the company (Zhang et al., 2014), (2) corporate financial performance (ROE), measured by the ratio of after tax profit to equity (Clacher and Hagendorff, 2012), and (3) employee productivity (PDCT), measured by the ratio of EBIT to number of employees (Clacher and Hagendorff, 2012).

Since we introduced CARs that were expected to be positive and negative in the analysis, it was also necessary to control for this opposite effect. Therefore, to carry out the empirical analysis we defined a dummy variable (SIG) that took the value one for the CSR news that were coded as positive and zero for the CSR news that were coded as negative. All 
the variables were included in the model specification interacting with this dummy, so we could study the effect of each variable in the event of positive and negative returns.

In order to test the hypotheses, the coefficients of the model and the interaction variables were interpreted. For example, in the case of the CSR news related to the community, the null hypothesis $\mathrm{H}_{0}: \alpha_{1}=0$ was tested. If this null hypothesis was rejected, then the coefficient $\alpha_{1}$ had to be statistically different from zero, which indicated the sensitivity of the CAR to the negative piece of news related to the community. To interpret the interaction variables correctly, it was also necessary to perform a linear restriction test. In this regard, and following the same example of the community stakeholder, if the null hypothesis $\mathrm{H}_{0}: \alpha_{1}+\varphi_{1}=0$ was rejected, the sum of coefficients would be statistically different from zero, capturing the estimation of the sensitivity of the CAR to the positive piece of news related to the community. For all the variables, we followed the same pattern to analyse the findings: the individual coefficients $\left(\alpha_{1} ; \alpha_{2} ; \alpha_{3} ; \alpha_{4} ; \alpha_{5} ; \alpha_{6} ; \alpha_{7}\right)$ measured the sensitivity of the CAR to negative news, while the sum of coefficients $\left(\alpha_{1}+\varphi_{1} ; \alpha_{2}+\varphi_{2} ; \alpha_{3}+\varphi_{3} ; \alpha_{4}+\varphi_{4} ; \alpha_{5}+\varphi_{5} ; \alpha_{6}+\varphi_{6} ; \alpha_{7}+\right.$ $\left.\varphi_{7}\right)$ measured the sensitivity of the CAR to positive news.

In addition, to compare the relevance of each variable in our model, the standardized coefficients were calculated for all the variables. This estimation enabled us to remove the scale effect from the estimated coefficients and determine which factors had the greatest influence on the dependent variable.

\section{Study 2 - Findings}

Table II shows the results of the regression analysis.

\section{Insert Table II about here}

Concerning the CSR news that were expected to generate negative market reactions, we found direct effects of the CSR news related to the community $\left(\alpha_{1}=-0.114, \mathrm{p}<0.05\right)$, customers $\left(\alpha_{2}=-0.156, \mathrm{p}<0.05\right)$, employees $\left(\alpha_{3}=-0.123, \mathrm{p}<0.05\right)$ and investors $\left(\alpha_{4}=-0.176\right.$, 
$\mathrm{p}<0.01)$. For all these variables, the coefficients were negative and significant. Thus, the findings confirmed that the announcement of CSR news with negative content related to these four CSR topics provoked a negative reaction in the share prices of the companies under scrutiny. Nonetheless, and according to the standardized coefficients, the CSR news related to investors caused the greatest negative abnormal returns (Beta=-2.296), followed by those related to customers (Beta=-2.188), the community (Beta=-1.636) and employees (Beta=1.319). As far as positive CSR news was concerned, we only found direct effects for news related to employees $\left(\alpha_{3}+\varphi_{3}=0.048, \mathrm{p}<0.05\right)$.

In addition, Table II also shows that the standardized coefficients were smaller in the case of positive CSR news than negative CSR news. Thus, we can conclude that the market reaction was frequently stronger under the release of negative CSR news.

It is also worth noticing that none of the control variables analyzed in the paper had any significant effect in the model when both negative and positive CSR news were explored.

Overall, the findings of the regression analysis allowed us to confirm the third hypothesis of our paper (H3) only partially. More precisely, the findings showed that, indeed, CSR media coverage had a stronger impact on companies' significant (abnormal) returns for (negative) investors' and customers' news than (negative) community news. Also, (positive) employees' news were the only type of (positive) CSR news that provoked a significant reaction of the stock market. Thus, there seems to be some evidence that, when taking their investment decisions, shareholders appreciate CSR information that affects primary stakeholders especially. However, the market reaction to the (negative) community news was larger than the reaction to (negative) employees' news. Thus, we could not conclude that CSR news focused on secondary stakeholders were always less important for shareholders than CSR news focused on primary stakeholders. 


\section{DISCUSSION}

As a first interesting finding, the results of the study confirm the relevance of media coverage

of CSR news to satisfy corporate financial goals. More precisely, the empirical study undertaken in this research demonstrates that the tone of the media coverage of CSR news plays a significant role in determining market reactions. In this regard, while positive news have a positive impact on the share price changes experienced by companies in the stock market (H1a accepted), news including negative connotations have a negative effect on the market value of companies' shares (H1b accepted). These findings align with the results of previous scholars who have also explored CFP with market-based measures (Curran and Moran, 2007; Flammer, 2013; Wright et al., 1995), while they are inconsistent with the inconclusive findings reported when accounting-based measures are analyzed (Hendarto and Purwanto, 2012). This can be so due to the interpretation of CSR as a cost to the company, which clearly damages performance accounting measures. On the contrary, market measures are based on perceptions and subjective valuations carried out by shareholders who value the financial performance of the company not only in quantitative terms but also in qualitative terms, that is, assessing the quality of the actions carried out within the company and anticipating sustained performance over time (Frooman, 1997). Thus, far from being mere costs that detract from CFP, CSR expenditures must be understood as strategic investments for the long-term benefit of the company, which also depends on the positive market reactions to consolidate its financial value.

Along this line, the findings have also highlighted the asymmetric impact of positive and negative CSR news on the market value of companies, corroborating the second hypothesis of the paper (H2). In this regard, it has been demonstrated that shareholders react more strongly to CSR news that have negative (vs. positive) implications for their stakeholders. As previously defended in academic literature, this finding corroborates that irresponsible corporate actions 
result in substantial decreases in shareholders' wealth that are difficult to recover despite the release of positive CSR news (Curran and Moran, 2007).

In addition, it has also been observed that the most significant reaction of the stock market to positive and/or negative CSR news is quite immediate. The findings of this research show that the most intense effect of CSR news on the abnormal returns for companies occurs within a 3-day timeframe $([-1 ;+1])$, while it diminishes over time and it becomes insignificant when longer timeframes are considered (e.g., $[-1 ;+5])$. This finding is consistent with the results reported by previous scholars, such as Shane \& Spicer (1983), who show that the average abnormal returns aggregated for the dates around the release of the first environmental report of a company are much larger than for the following days and even reports.

As far as the last hypothesis of the paper (H3) is concerned, the findings confirm that CSR news related to primary or secondary stakeholders result in different market reactions and abnormal returns for companies. Nonetheless, the results are ambiguous in this regard and the hypothesis is supported only partially. As a consequence, it is not possible to derive general, conclusive interpretations about how each type of CSR news affect shareholders' investment decisions.

Roughly speaking, the findings of our regression analysis align with the general premises of the managerial perspective of the stakeholder theory (Freeman, 1984), which defends that not all stakeholders are equally salient, and as so they do not have the same power to influence a company's performance. More precisely, it is demonstrated that shareholders' always react more strongly to CSR news when they refer to primary stakeholders such as investors, customers and employees. On the contrary, the effect of CSR news focused on the community are not that intense. In this regard, primary stakeholders are especially salient groups that have the power, legitimacy and urgency to influence corporate behavior and performance in the short-run (Mitchell et al., 1997). Therefore, CSR news focused on what 
companies do to benefit (or damage) primary stakeholders' wellness affect their profit-making ability and, as a consequence, they attractiveness in the stock market (Halme and Laurila, 2009). On the contrary, and even though secondary stakeholders can also affect a company's reputation and attractiveness in the stock market, they are less salient for companies because they do not have a direct impact in corporate profit-making ability or survival in the long-run (van der Laan et al., 2008).

However, the findings of this research do not allow us to identify a clear classification of stakeholders as primary or secondary groups, which could assist companies in prioritizing their CSR actions according to their positive or negative impact in their market value. On the one hand, investors' and customers' issues are especially salient for shareholders' investment decision-making when negative CSR information is released. The effect of these types of negative CSR news on the abnormal returns for companies is significantly larger than the effect of negative CSR news related to the community and employees. On the contrary, after the eventual release of positive CSR news, information related to employees' issues demonstrates to be more effective to improve market value than any other type of CSR information. Actually, positive CSR news focused on employees' issues are the only ones that provoke significant positive returns for companies.

We believe that these differences among diverse types of CSR news can be explained by the impact that each positive or negative CSR news has on the resources of companies, their productivity and their ability to generate future cash flows. On the one hand, investors control money, which is the most critical resource for the continued viability of a company (Morf et al., 2013). Similarly, companies strongly depend on customers because of their ability to threaten the company's existence in terms of lost business and cash flows (Elijido-Ten et al., 2010). Therefore, negative news related to these two stakeholder groups can especially affect a company's attractiveness in the stock market because they directly threaten the company's 
ability to generate future profits for shareholders. On the contrary, employees fall under what scholars define as the 'company power relationship' (Elijido-Ten et al., 2010), that is, they are stakeholders who depend on the company for their economic survival and stability. This being so, negative news concerning employees' issues might only have a moderate impact on a company's ablity to generate profits, whereas positive news can derive into higher employee motivation and productivity, affecting future cash flows more significantly and positively.

\section{CONCLUSIONS, LIMITATIONS AND FUTURE LINES OF RESEARCH}

In this paper, we have explored the relationship that exists between media coverage of diverse types of corporate social responsibility (CSR) news and corporate financial performance (CFP), measured as the value of companies in the stock market. In this regard, scholars have traditionally concentrated on analyzing CFP with accounting-based measures, reporting inconsistent findings on the relationship between CSR and CFP. Also along this line, most of the previous studies that have explored the relationship between CSR news and stock prices have focused on exploring only very specific CSR topics, such as environmental, labor or philanthropic issues. However, the stakeholder theory defends the multidimensional character of CSR and the large variety of stakeholder demands that companies should balance. Thus, further research was needed to compare the effects of diverse types of CSR news on the market value and reactions to media news.

In summary, the findings reported in the paper suggest that the media coverage of CSR news always has a significant effect on the CFP of companies, at least in the short-run. While positive news generate some positive abnormal returns, negative news frequently provoke strong negative abnormal returns. In addition, differences also exist in the effects of CSR news focused on primary and secondary stakeholders on corporate market value, although the findings are ambiguous and inconclusive in this regard. Both positive and negative CSR news 
related to some primary stakeholders (i.e., customers, employees and investors) provoke larger market reactions than positive and negative CSR news related to secondary stakeholders (i.e., community). However, the findings are not consistent across positive and negative news because CSR news focused on different stakeholders do not follow a homogeneous trend.

These findings have significant implications for the management of CSR and media relations in companies. First, companies should realize the importance that CSR has acquired in recent years, which recommends that they do not take it as a cost or think about it in the short term. Companies should apply a long-term strategic approach to CSR because it does have an important effect on their market value. Closely related to this idea, when companies evaluate their CSR performance in financial terms, they should better choose to analyze CFP with market-based measures instead of accounting metrics as the results are much more consistent and apparently reliable. Third, we would also like to highlight the relevance of the public relations function of the company to manage its relationships with the media as this research has demonstrated their importance to determine the CFP performance of companies and, therefore, the effectiveness of their CSR actions. An adequate design of their public relations strategy would surely enhance the publicity of positive news while minimizing the negative impact of CSR crises. Fourth, there is a clear need that companies give more presence to some specific CSR actions over others that have a lower impact on corporate market value. It has been observed that the impact of different types of CSR news on corporate market value is asymmetric, something closely related to the salience of each stakeholder group. Thus, it is important that companies constantly analyze the power, legitimacy and urgency of each stakeholder to focus on those groups that have the most impact on the success of the corporate strategy in each specific moment of time. One last important issue that CSR managers should take into account relates to the correct selection of the precise moment in which CSR announcements should be made. In this regard, we know that the effect of CSR news is quite 
immediate, that is, CSR news provoke a strong reaction in shareholders' minds in the shortrun. Thus, companies should select the announcement day carefully to maximize its positive impact on their market value.

Finally, this study is not without limitations and future research should consider them to improve the knowledge on media coverage, CSR and CFP. In this regard, this study took only a snapshot view of media's stance on CSR in Spain because it only examined the content of a specialist business newspaper in the country. Therefore, the findings may not represent the full spectrum of CSR issues covered in Spanish media as there are other types of general newspapers that also cover CSR issues (general vs. specialist newspapers). In addition, the study was only concerned with Spanish news, which limits the generalizability of the results to other research contexts. Finally, the study only covered articles published in a time frame of one year. This fact represents a relevant limitation of the study because it means that the findings are likely to be influenced by the specific economic, social or political situation of the country in the year of the analysis. Based on these limitations, future researchers should propose analyses that include a broader spectrum of media, countries and time frames that reduce the biases that may have been found in the present paper.

\section{REFERENCES}

Aaron, J.R., McMillan, A. and Cline, B.N. (2012), "Investor reaction to firm environmental management reputation", Corporate Reputation Review, Vol. 15 No. 4, pp. 304-318.

Bentolila, S., Cahuc, P., Dolado, J.J. and Barbanchon, T.L. (2010), Unemployment and Temporary Jobs in the Crisis: Comparing France and Spain, No. 2010-07.

Carroll, C.E. and McCombs, M. (2003), “Agenda-setting effects of business news on the public's images and opinions about major corporations", Corporate Reputation Review, Vol. 6 No. 1, pp. 36-46. 
Casciaro, T. and Piskorski, M.J. (2005), "Power imbalance, mutual dependence, and constraint absorption: A closer look at resource dependence theory", Administrative Science Quarterly, Vol. 50 No. 2, pp. 167-199.

Clacher, I. and Hagendorff, J. (2012), “Do announcements about corporate social responsibility create or destroy shareholder wealth? Evidence from the UK", Journal of Business Ethics, Vol. 106 No. 3, pp. 253-266.

Clarkson, M.B.E. (1995), “A stakeholder framework for analyzing and evaluating corporate social performance”, Academy of Management Review, Vol. 20 No. 1, pp. 92-117.

Curran, M.M. and Moran, D. (2007), "Impact of the FTSE4Good Index on firm price: An event study", Journal of Environmental Management, Vol. 82 No. 4, pp. 529-537.

Dodd, P. and Warner, J.B. (1983), “On corporate governance: A study of proxy contest”, Journal of Financial Economics, Vol. 11 No. 1-4, pp. 401-438.

Elijido-Ten, E., Kloot, L. and Clarkson, P. (2010), “Extending the application of stakeholder influence strategies to environmental disclosures: An exploratory study from a developing country", Accounting, Auditing \& Accountability Journal, Vol. 23 No. 8, pp. $1032-1059$.

Flammer, C. (2013), “Corporate social responsibility and shareholder reaction: The environmental awareness of investors", Academy of Management Journal, Vol. 56 No. 3, pp. $758-781$.

Fombrun, C.J., Gardberg, N.A. and Sever, J.M. (2000), “The reputation quotientSM: A multistakeholder measure of corporate reputation”, Journal of Brand Management, Vol. 7 No. 4, pp. 241-255.

Freeman, R.E. (1984), Strategic Management: A Stakeholder Approach, Pittman, Boston, MA.

Frooman, J. (1997), "Socially irresponsible and illegal behaviour and shareholder wealth", 
Business and Society, Vol. 36 No. 3, pp. 221-249.

Gibson, K. (2000), "The moral basis of stakeholder theory”, Journal of Business Ethics, Vol. 26 No. 3, pp. 245-257.

Godfrey, P.C., Merrill, C.B. and Hansen, J.M. (2009), “The relationship between corporate social responsibility and shareholder value: An empirical test of the risk management hypothesis", Strategic Management Journal, Vol. 30 No. 4, pp. 425-445.

Gómez, F. and Lyczkowska, K. (2014), "Spanish courts, the court of justice of the European Union, and consumer law”, InDret: Revista Para El Análisis Del Derecho, Vol. 4 No. October, pp. 1-34.

Guo, L. and Mech, T.S. (2000), “Conditional event studies, anticipation, and asymmetric information: The case of seasoned equity issues and pre-issue information releases", Journal of Empirical Finance, Vol. 7 No. 2, pp. 113-141.

Halme, M. and Laurila, J. (2009), "Philanthropy, integration or innovation? Exploring the financial and societal outcomes of different types of corporate responsibility", Journal of Business Ethics, Vol. 84 No. 3, pp. 325-339.

Hendarto, K.A. and Purwanto, B.M. (2012), "Market reactions of mandatory implementation of corporate social responsibility: Indonesia context", Asia Pacific Management Review, Vol. 17 No. 4, pp. 379-402.

Jensen, M.C. (2002), "Value maximization, stakeholder theory, and the corporate objective function", Business Ethics Quarterly, Vol. 12 No. 2, pp. 235-256.

Klassen, R.D. and McLaughlin, C.P. (1996), “The impact of environmental management on firm performance", Management Science, Vol. 42 No. 8, pp. 1199-1214.

Luo, J., Meier, S. and Oberholzer-Gee, F. (2012), No News Is Good News: CSR Strategy and Newspaper Coverage of Negative Firm Events, No. 12-091.

McCombs, M. and Reynolds, A. (2002), "News influence on our pictures of the world", in 
Bryant, J. and Zillmann, D. (Eds.), Media Effects, 2nd editio., Mahwah, NJ, pp. 1-16.

McWilliams, A. and Siegel, D. (1997), "Event studies in management research: Theoretical and empirical issues", Academy of Management Journal, Vol. 40 No. 3, pp. 626-657.

Mitchell, R.K., Wood, D.J. and Agle, B. (1997), “Toward a theory of stakeholder identification and salience: Defining the principle of who and what really counts", Academy of Management Review, Vol. 22 No. 4, pp. 853-886.

Morf, D., Flesher, D.L., Hayek, M., Pane, S. and Hayek, C. (2013), "Shifts in corporate accountability reflected in socially responsible reporting: a historical review", Journal of Management History, Vol. 19 No. 1, pp. 87-113.

Palau, A.M. and Davesa, F. (2013), “The impact of media coverage of corruption on Spanish public opinion”, Revista Española de Investigaciones Sociológicas, Vol. 144 No. 1, pp. 97-124.

Patten, D.M. (2008), "Does the market value corporate philanthropy? Evidence from the response to the 2004 tsunami relief effort”, Journal of Business Ethics, Vol. 81 No. 3, pp. 599-607.

Pérez, A., García de los Salmones, M. del M. and López-Gutiérrez, C. (2015), “Corporate reputation in the Spanish context: An interaction between reporting to stakeholders and industry", Journal of Business Ethics, Vol. 129 No. 3, pp. 733-746.

Pérez, A., López-Gutiérrez, C. and García de los Salmones, M. del M. (2017), “An empirical exploration of the link between reporting to stakeholders and corporate social responsibility reputation in the Spanish context", Accounting, Auditing \& Accountability Journal, Vol. 30 No. 3, pp. 668-698.

Shane, P.B. and Spicer, B.H. (1983), "Market response to environmental information produced outside the firm", The Accounting Review, Vol. 58 No. 3, pp. 521-538. Shiu, Y.-M. and Yang, S.-L. (2017), "Does engagement in corporate social responsibility 
provide strategic insurance-like effects?", Strategic Management Journal, Vol. 38 No. 2, pp. $455-470$.

Tang, L. (2012), "Media discourse of corporate social responsibility in China: A content analysis of newspapers", Asian Journal of Communication, Vol. 22 No. 3, pp. 270-288.

Ullmann, A.A. (1985), "Data in search of a theory: A critical examnation of the relationships among social performance, social disclosure, and economic performance of U.S. firms", Academy of Management Review, Vol. 10 No. 3, pp. 540-557.

del Valle, J.M. (2015), "Post-crisis social rights and social security law in Spain”, Spanish Labour Law and Employment Relations Journal, Vol. 4 No. 1, pp. 66-74.

van der Laan, G., van Ees, H. and van Witteloostuijn, A. (2008), "Corporate social and financial performance: An extended stakeholder theory, and empirical test with accounting measures”, Journal of Business Ethics, Vol. 79 No. 3, pp. 299-310.

Verick, S. (2009), Who Is Hit Hardest during a Financial Crisis? The Vulnerability of Young Men and Women to Unemployment in an Economic Downturn, No. 4359, Bonn.

Wright, P., Ferris, S.P., Hiller, J.S. and Kroll, M. (1995), “Competitiveness through management of diversity: Effects on stock price valuation”, Academy of Management Journal, Vol. 38 No. 1, pp. 272-287.

Xu, X.D., Zeng, S.X. and Tam, C.M. (2012), “Stock market's reaction to disclosure of environmental violations: Evidence from China", Journal of Business Ethics, Vol. 107 No. 2, pp. 227-237.

Zhang, J. and Swanson, D. (2006), “Analysis of news media's representation of corporate social responsibility (CSR)”, Public Relations Quarterly, Vol. 51 No. 2, pp. 13-17.

Zhang, L., Wang, T. and Fung, H. (2014), "Market reaction to corporate social responsibility announcements: Evidence from China", China \& World Economy, Vol. 22 No. 2, pp. $81-101$. 


\section{APPENDIX}

\section{Insert Table III about here}

Insert Figure 1 about here

This piece of news, entitled "Iberdrola, Acciona and other 41 international companies join forces against climate change", describes the agreement letter that 43 CEOs have signed to reivindicate a global climate agreement at the Paris Summit 2015. Based on the codification protocol created by the authors to select and classify CSR news for the study, this headline was coded as follows:

Insert Table IV about here 
Table I: Study 1 - event study results

\begin{tabular}{|c|c|c|c|c|c|c|c|}
\hline $\begin{array}{l}\text { Expected sign } \\
\mathrm{N}\end{array}$ & & $\begin{array}{l}\text { Positive } \\
159\end{array}$ & \multicolumn{3}{|c|}{$\begin{array}{c}\text { Negative } \\
36\end{array}$} & \multicolumn{2}{|c|}{$\begin{array}{l}\text { Wilcoxon rank- } \\
\text { sum test }\end{array}$} \\
\hline Event window & ACAR & $\begin{array}{c}\text { Dodd \& Warner } \\
(1983)\end{array}$ & ACAR & $\begin{array}{r}\text { Dodd \& } \\
(198 \\
\end{array}$ & $\begin{array}{l}\text { Warner } \\
33 \text { ) }\end{array}$ & \multicolumn{2}{|c|}{$\mathrm{Z}$} \\
\hline$[-3,-1]$ & $-0.13 \%$ & -0.056 & $-0.72 \%$ & -1.242 & & 23.638 & $* * *$ \\
\hline$[-2,-1]$ & $0.04 \%$ & 0.965 & $-1.74 \%$ & -3.708 & . & 87.109 & $* * *$ \\
\hline$[-1]$ & $0.02 \%$ & 0.615 & $-0.66 \%$ & -2.616 & $* * *$ & 76.266 & $* * *$ \\
\hline$[-1,+1]$ & $0.51 \%$ & $3.003 * * *$ & $-2.75 \%$ & -4.753 & $* * *$ & 63.012 & $* * *$ \\
\hline$[-1,+2]$ & $0.23 \%$ & 0.975 & $-1.92 \%$ & -3.130 & $* * *$ & 81.038 & $* * *$ \\
\hline$[-1,+3]$ & $0.18 \%$ & 0.852 & $-1.85 \%$ & -2.780 & $* * *$ & 91.263 & $* * *$ \\
\hline$[-1,+4]$ & $0.24 \%$ & 0.740 & $-2.43 \%$ & -2.799 & $* * *$ & 92.799 & $* * *$ \\
\hline$[-1,+5]$ & $0.08 \%$ & 0.166 & $-1.98 \%$ & -1.802 & & 109.659 & $* * *$ \\
\hline
\end{tabular}


Table II: Study 2 - regression analysis results

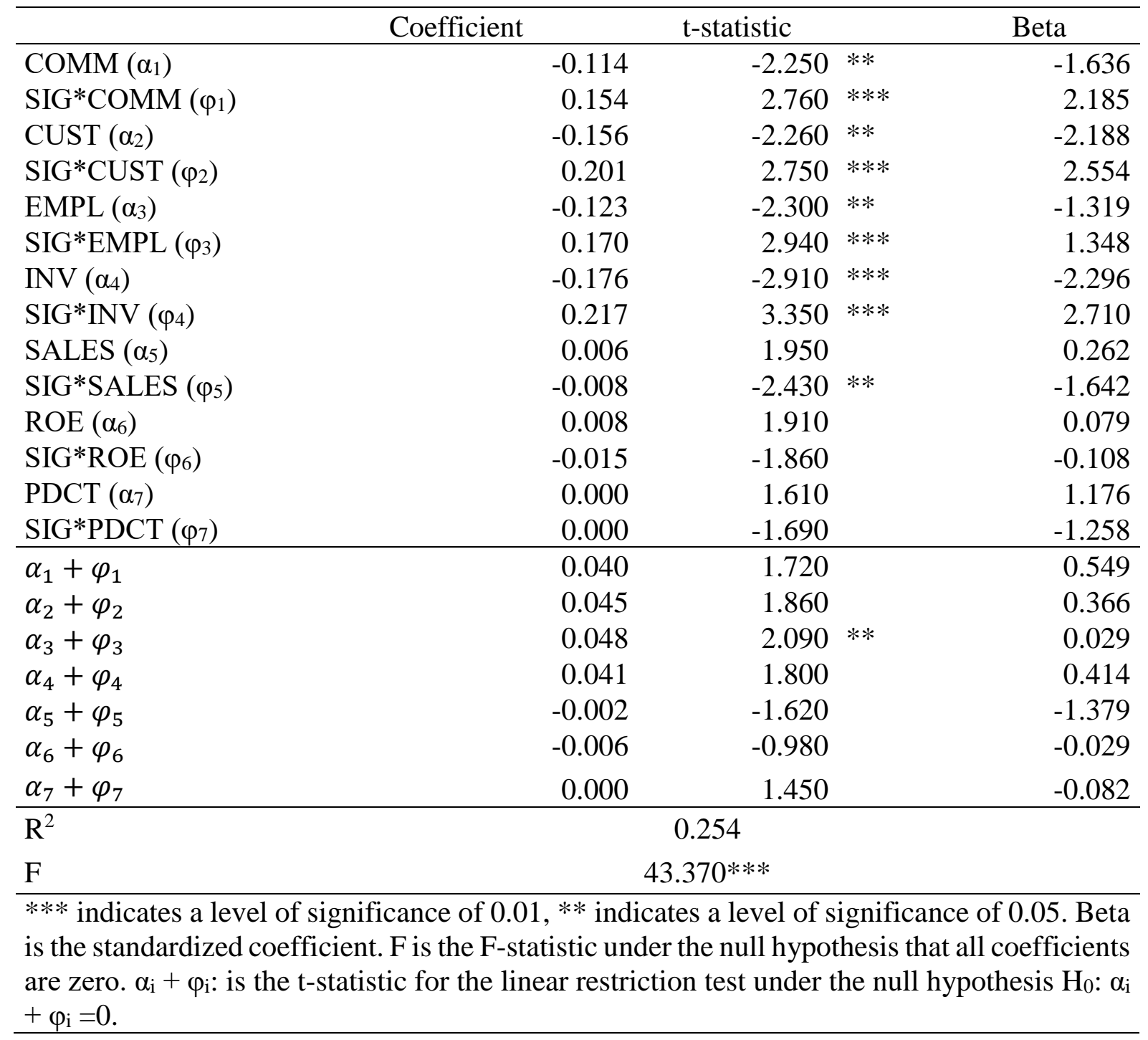


Table III: Selection of CSR topics to classify the types of CSR news covered by the media

\begin{tabular}{|c|c|}
\hline Stakeholder & CSR topic \\
\hline Community & $\begin{array}{l}\text { Economic development programs } \\
\text { Environmental policy, systems and performance } \\
\text { Educational and cultural contribution } \\
\text { Social and charitable contribution }\end{array}$ \\
\hline Customers & $\begin{array}{l}\text { Development of products to meet the special needs of the disadvantaged } \\
\text { Competitive prices and payment conditions } \\
\text { Customer service, relations, communication and dialogue mechanisms } \\
\text { High innovation and accessibility } \\
\text { High product quality, health and safety } \\
\text { Standards, voluntary codes and transparency for marketing practices }\end{array}$ \\
\hline Employees & $\begin{array}{l}\text { Job creation and stability } \\
\text { Social benefits } \\
\text { Freedom of association, collective bargaining and complaint procedures } \\
\text { Equal opportunities } \\
\text { Training and development }\end{array}$ \\
\hline Investors & $\begin{array}{l}\text { Investor rights } \\
\text { Investor relations, communication and dialogue mechanisms } \\
\text { Complaint procedures } \\
\text { Provision of all required information to credit rating agencies }\end{array}$ \\
\hline
\end{tabular}


Table IV: Example of the codification procedure used to select and classify CSR news

\begin{tabular}{ccccccc}
\hline Event date & $\begin{array}{c}{[-5 ;+5]} \\
\text { window }\end{array}$ & Company & Industry & Stakeholder & CSR Topic & Tone \\
\hline \multirow{3}{*}{$17 / 04 / 2015$} & $\begin{array}{c}{[12 / 04 / 2015 ;} \\
22 / 04 / 2015]\end{array}$ & $\begin{array}{l}\text { Iberdrola } \\
\text { (www.iberdrola.es) }\end{array}$ & $\begin{array}{c}\text { Energy } \\
\text { industry }\end{array}$ & $\begin{array}{c}\text { Community } \\
\text { (environment) }\end{array}$ & $\begin{array}{c}\text { Environmental } \\
\text { policy, } \\
\text { systems and } \\
\text { performance }\end{array}$ & Positive \\
\hline
\end{tabular}


Figure 1. Example of a piece of CSR news included in the database of the research

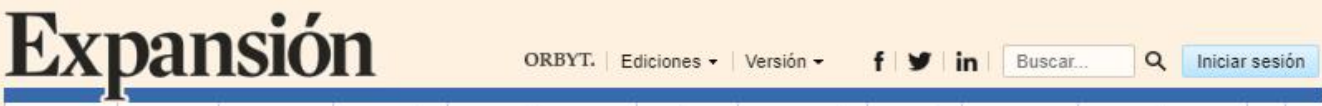 \\ MERCADOS AHORRO EMPRESAS ECONOMIA EXPANSIÓN\&EMPLEO JURIDICO TECNOLOGIA OPINIÓN DIRECTIVOS ECONOMIA DIGITAL + \\ Empresas Energía Banca Tecnológicas Construcción e Inmobiliario Distribución Transporte Industria Motor}

ENERGIA

Iberdrola, Acciona y otras 41 compañías internacionales se alían contra el cambio climático
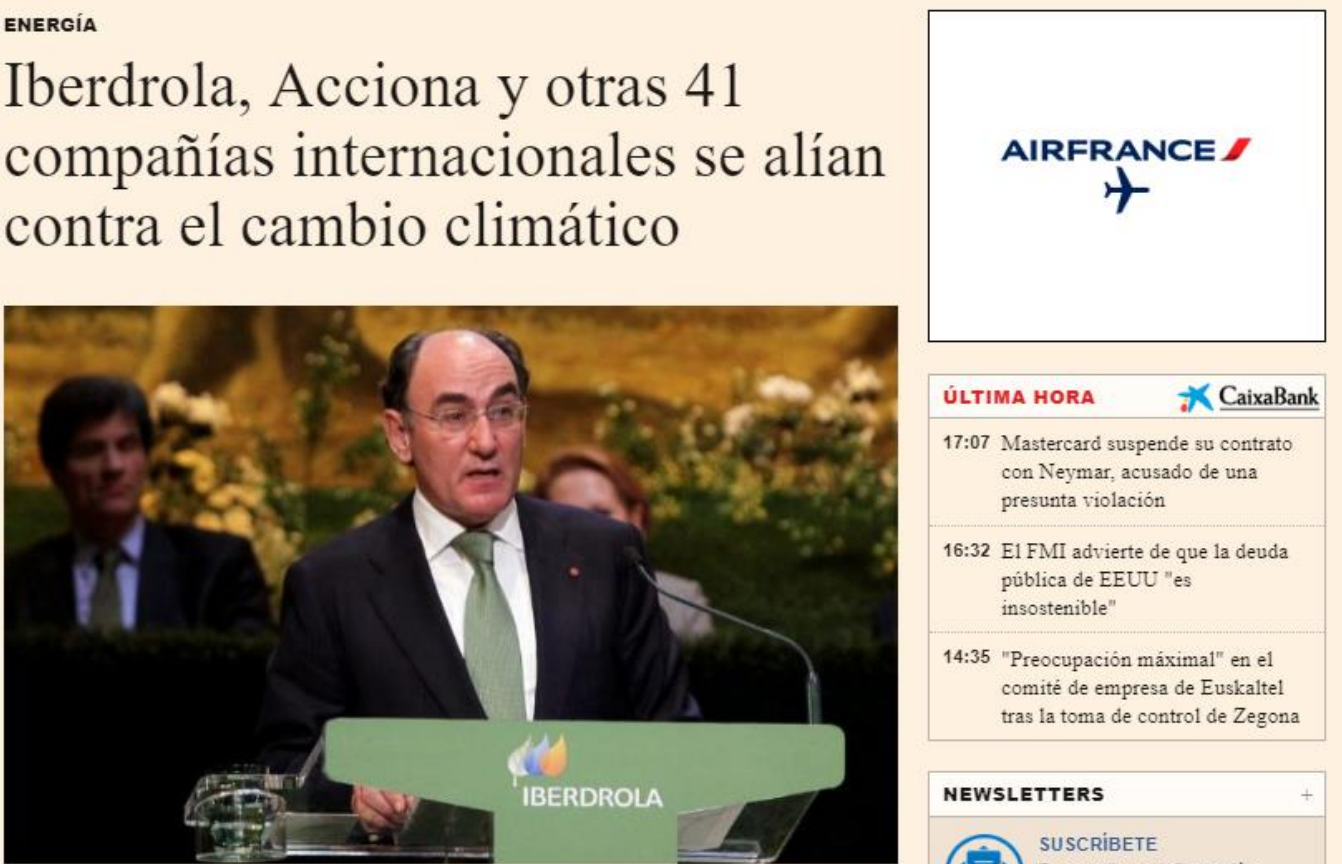

El presidente de lberdrola, Ignacio Sánchez Galán. | F.RODRIGUEZ | EXPANSION

ÚlTima HORA † CaixaBank

17:07 Mastercard suspende su contrato

con Neymar, acusado de una presunta violación

16:32 E1 FMI advierte de que la deuda pública de EEUU "es

insostenible

14:35 "Preocupación máximal" en el comite de empresa de Euskaltel tras la toma de control de Zegona

\section{NEWSLETTERS}

SUSCRIBETE

Personaliza la información

económica que quieres recibir por secciones. 